\title{
An ethnobotanical study in Midyat (Turkey), a city on the silk road where cultures meet
}

\author{
Ali Akgull ${ }^{1 *}$, Ayfer Akgul $^{2}$, Serdar G. Senol ${ }^{3}$, Hasan Yildirim ${ }^{3}$, Ozcan Secmen $^{4}$ and Yunus Dogan ${ }^{5}$
}

\begin{abstract}
Background: Studies of ethnobotanical usages in south-eastern Turkey are rare. To widen this field of knowledge, we conducted an ethnobotanical study in Midyat (Mardin Province), Turkey.

Methods: The field study was completed during three years (2007-2010). Our aim was to document the ethnobotanical uses of local plants and to make an ethnobotanical inventory of uncommon plants using qualitative interviews.

Results: During field studies, 368 voucher specimens were collected in the investigated area. Ninety-two traditionally used plant species were reported from Midyat and surrounding vicinities in Turkey. Among the 92 taxa (129 usages), 35\% were used for medical purposes, 22\% for food, 13\% for animal fodder, $7 \%$ as ornamental plants and dyes, $6 \%$ as brooms, $4 \%$ for latex and as fragrance, $4 \%$ for herbal tea, molasses and wine preparation, 3\% for agricultural purposes, and 6\% for other purposes. Comparative assessment showed that Teucrium polium (0.51), Matricaria aurea (0.26), Alcea setosa (0.21), and Malva neglecta (0.21) have the highest recorded UVs, and the following taxa had UVs between 0.10-0.20: Anthemis cotula (0.12), Allium cepa (0.13), Alcea striata subsp. striata (0.14), Crupina crupinastrum (0.12), Papaver rhoeas (0.13), Salvia multicaulis (0.14), Thymbra spicata (0.11), and Vicia pannonica subsp. striata (0.15). We reported the ethnobotanical usages of 21 taxa for the first time, in addition to indicating usages previously recorded in the literature. We also recorded four endemic plant usages in the area: Alkanna trichophila var. mardinensis, Centaurea kurdica, Centaurea stapfiana, and Sideritis libanotica subsp. linearis. They have variable leaf and flower morphology that are used traditionally. They are present as well-developed populations and thus their conservation status is not compromised. Additionally, Thymbra sintenisii is a recorded species that is classified as a rare and extensively used species in the region.

Conclusions: These results contribute to the fundamental knowledge of ethnobotanical usages in Midyat. To date, ethnobotanical studies have not been carried out in this region. This investigation uncovered usages of endemic medicinal plant species and traditional knowledge of Midyat communities living in a mixed culture. The people of Midyat, Batman, and Şırnak are Turkish citizens from various ethnic backgrounds, such as Kurdish, Arabic, and Syriac. We compared our data with results from other studies conducted in Turkey, particularly in south-eastern and eastern regions, as well as with studies from bordering countries, Iraq, Jordan, Syria, and Iran. Nonetheless, more work needs to be conducted to extend the present knowledge for locals to contribute to and evaluate economic potential in the region.
\end{abstract}

Keywords: Ethnobotany, Midyat, Medicinal plant, Turkey, Useful plants

\footnotetext{
* Correspondence: aliakgul@ufl.edu

'Department of Infectious Diseases \& Pathology, College of Veterinary

Medicine, University of Florida, Gainesville, FL, USA

Full list of author information is available at the end of the article
} 


\section{Background}

Traditional knowledge of plants has always been transferred from generation to generation throughout the natural course of everyday life [1]. This important knowledge, collated through ethnobotanical studies, is valuable for conservation, and establishment of the local and indigenous plant usages has significant benefits [2]. Turkey has an enormous potential for the exploration of new ethnobotanical usages because of its extremely rich plant diversity [3]. The Turkish flora comprises more than 11,700 plant taxa (about $30 \%$ of these are endemic taxa) [4], and the Turkish people have a broad knowledge of folkloric medicines; therefore, Turkey represents a huge resource for ethnobotanical usage studies [5]. Plants are commonly used by Turkish people for traditional remedies, as an herbal tea, food, spice, firewood, dye, furniture, agricultural tools, construction materials, and indoor plants [4]. Many ethnobotanical studies include general medical usage, but these studies are fewer in number than those about non-medical ethnobotanical usages [6].

Recently, botanists in Turkey have started using a different approach in ethnobotanical studies. When they conduct a floristic study in a specific area, an ethnobotanical survey study section is added [7]. Previous studies in Turkey have included a section of ethnobotanical usages at the end of the flora section.

Ethnobotanical studies have been on the increase in many regions of Turkey [1, 8-13]. In Midyat (Mardin Province, Turkey), people benefit from the diversity of flora by using plants as a rich source of medicine. Medicinal plants were used by Anatolian cultures, hence the accumulation of large amounts of remarkable medicinal folk knowledge in the region [14]. Although there are some studies in eastern Anatolia [15, 16], the southeast region of Anatolia is still a poor area in terms of ethnobotany studies. Midyat has a great diversity of plant species given its climatic variation and different ecological habitats. The different ways of life and rich culture in the districts of Midyat have created diverse ethnobotanical usages. One of the oldest traditional plant usages is medicinal, which depends on knowledge and practical experience of using these natural materials. As far as the authors know, this is the first ethnobotanical study conducted in Midyat, Turkey. The primary objective of this study was to identify and document the medicinal ethnobotanical plants and associated ethnobotanical knowledge of the local people. The secondary purpose was to uncover new ethnobotanical usages such as endemic and endangered plant usages, and to evaluate the plant usages in the different ethnic groups in the region.

\section{Methods}

\section{Study area}

This study was conducted in Midyat, located at $37^{\circ} 25^{\prime}$ $N-41^{\circ} 22^{\prime} \mathrm{E}$, in south-eastern Turkey (Fig. 1). The district is located in the south-eastern part of Anatolia. Midyat covers an area of $1394 \mathrm{~km}^{2}$ and is located at $1070 \mathrm{~m}$ above sea level. The region is rugged and not surrounded by high mountains [17]. The population is 105,952 (2015). In Midyat, there is not only a mixture of cultures, but also a mixture of religions: Syriacs (Christian), Yexidians and Muslims have lived together for thousands of years. Four different languages, Turkish, Arabic, Syriac, and Kurdish, are spoken in this region. For example, in Eglence, a village in the region, people speak Arabic and Kurdish in their daily life. In a Christian village, Haberli, local people speak Arabic, Syriac, and Kurdish. Additionally, in all locations Turkish is the official language; therefore, all young generations speak Turkish very well.

\section{Socio-economic profile}

In Midyat, agriculture, husbandry, and handcrafts are the most important sources of income for the region's economy. $66.8 \%$ of income in the area is from husbandry and agriculture [18]. Traditional hand-made silver products and hand-crafted stonework, fabric painting, and jewelrymaking are still important [17]. The most important crops are wheat and barley, followed by cotton, pistachio, olives, grapes, apples, pears, plums, and walnuts [18].

\section{Ethnographic background}

Midyat, formerly known as Matiat, was built in the ninth century BCE by Syriac settlers, and a record of it was found written on Assyrian tablets [17]. The Silk Road is an historic route for overland travelers. The town of Mardin in south-eastern Turkey is an attraction of the Silk Road [19]. The Silk Road is more than just a trade route linking Asia and Europe; it is a display of cultures, ethnicities and religions that have settled in the region, and presents 2000 years of historical and cultural wealth [20]. From east to west, it was used in transporting silk, porcelain, paper, spices, and jewels for cultural exchange between continents [19].

During the Middle Ages, the Silk Road extended along multiple routes from Asia to Anatolia and from Thrace to Europe [21]. The Silk Road in the south of Anatolia passes by Mardin, Adıyaman, Kayseri, Konya, Denizli, and Antalya [19]. Mardin was also an important stopover point along the Silk Road due to its strategic position at the junction of two transit roads [17]. Before the Ottoman empire in the eleventh century, the Seljuk empire - a medieval Turko-Persian-Sunni Muslim empire - provided security by building caravanserais on these roads: there are five inns and caravanserais in Midyat in order to keep the commercial activities in Anatolia alive [19]. 


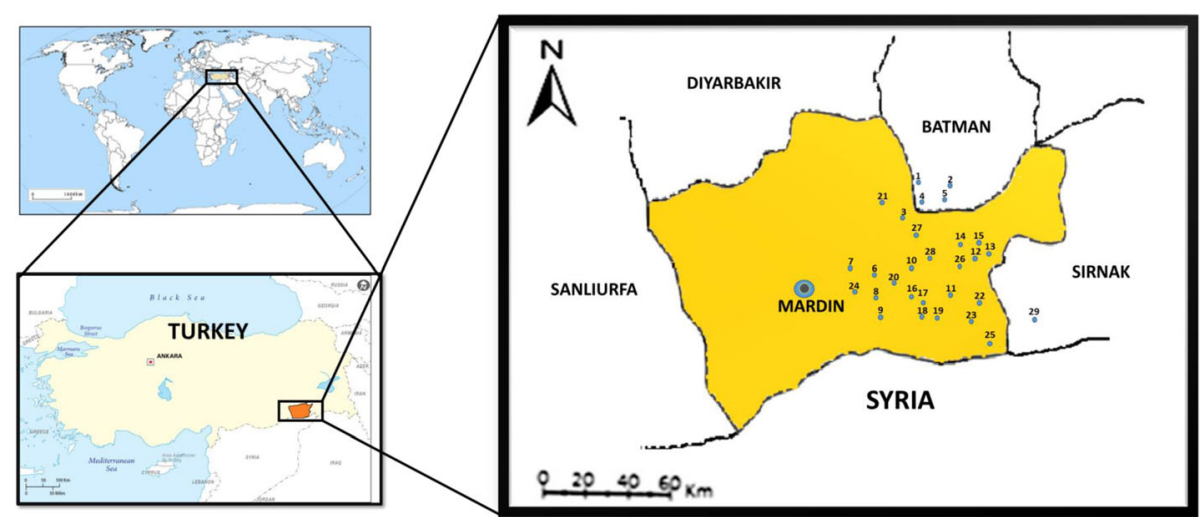

Fig. 1 Map of Midyat and districts. Provinces: 1-Doruk, 2-Tasci, 3-Sarikaya, 4-Tepecik, 5-Kayapinar, 6-Ziyaret, 7-Alicli, 8-Harmanli, 9-Camyurt, 10-Dogancay, 11-Yenice, 12-Baglarbasi, 13-Narli, 14-Baristepe, 15-Gulveren, 16-Yolbasi, 17-Pelitli, 18-Yemisli, 19-Sivrice, 20-Budakli, 21-Icoren, 22-Turgali, 23-Eglence, 24-Tepeli, 25-Yayvantepe, 26-Altintepe, 27-Senkoy, 28-Acirli, 29-Haberli

\section{Climate and topography}

Midyat is one of the most important floristic regions in south-eastern Turkey. The studied area has a potential to reflect the endemic characteristics of the Irano-Turanian flora and some xeric Indo-Malaysia forms. Summer is very hot, at an average of around $35{ }^{\circ} \mathrm{C}$ in June, and winter is cold, with an average temperature of $0.5^{\circ} \mathrm{C}$ in January [22].

The study was carried out from 2007-2010, March through late December, when plants were in flowering and fruiting periods. The information on the local names of plants, their usage and preparation were obtained from local citizens (123 respondents) through individual interviews. Most respondents were also asked about the source of their knowledge in order to eliminate information of secondary nature. This information was checked with that from other areas and neighboring villages in order to verify its accuracy. The plants were collected with the help of respondents. In the study area, different religions, languages, and ethnicities are present, which presented us with the advantage of being able to find new and preserved ethnobotanical knowledge from different cultures.

\section{Ethnobotanical data collection}

This study was conducted in Midyat to evaluate the usage of the natural plant flora. Information was gathered by interviewing 123 local people from 30 districts in Midyat and surrounding areas. People showed us plants from the field or dried samples from their properties for our records.

Identification of the specimens from our field collections revealed 92 taxa belonging to 32 plant families. These specimens were identified using the "Flora of Turkey" [23]; we compared them with the specimens in the Herbarium of Ege University, Izmir, Turkey, and listed the names of plant families in alphabetic order. The voucher specimens were also deposited in the Herbarium of Ege University. Plants were identified according to the International Plant
Name Index (IPNI: http://www.theplantlist.org/). Plant usages were examined by focusing on natural plant usages, not only on agricultural usages.

Ethno usages of the plants are given under their taxa names with voucher specimen numbers, in alphabetical order. In respective columns, the family, local name, preparation method, and used parts of the plants are recorded. The last column shows literature reports with references (Table 1).

\section{Interviews with local people}

Information was collected from locals by free-listed observations and semi-structured interviews of people in public areas (generally in fields, tea houses, mosques, churches, village squares, etc.). Local people talked about the collected plants in the fields; the people of Midyat are extremely generous in helping others whom they know. Especially in Midyat, we tried to obtain information from the oldest local people; however, several issues overshadowed data collection. First, people were scared of the threat of terror, which made it difficult to obtain any information. Second, communication sometimes caused problems because of the different languages that people speak in the region. This study was conducted in Turkish, but in order to reach all different groups, assistance was needed. We could only work with local people who spoke the local languages and who were familiar with the people in the area. By using local guidance, we conducted our interviews with local people without much difficulty. Since one of the authors has relations in the area, we got guidance from 15-20 locals with different backgrounds that spoke the same language as local people. We also used guidance to reach more people who have other ethnic or faith backgrounds, such as Syriac Christians. Similarly, teachers, imams (ministers) of mosques and churches, headmen of the villages, and the members of the security services of the villages 


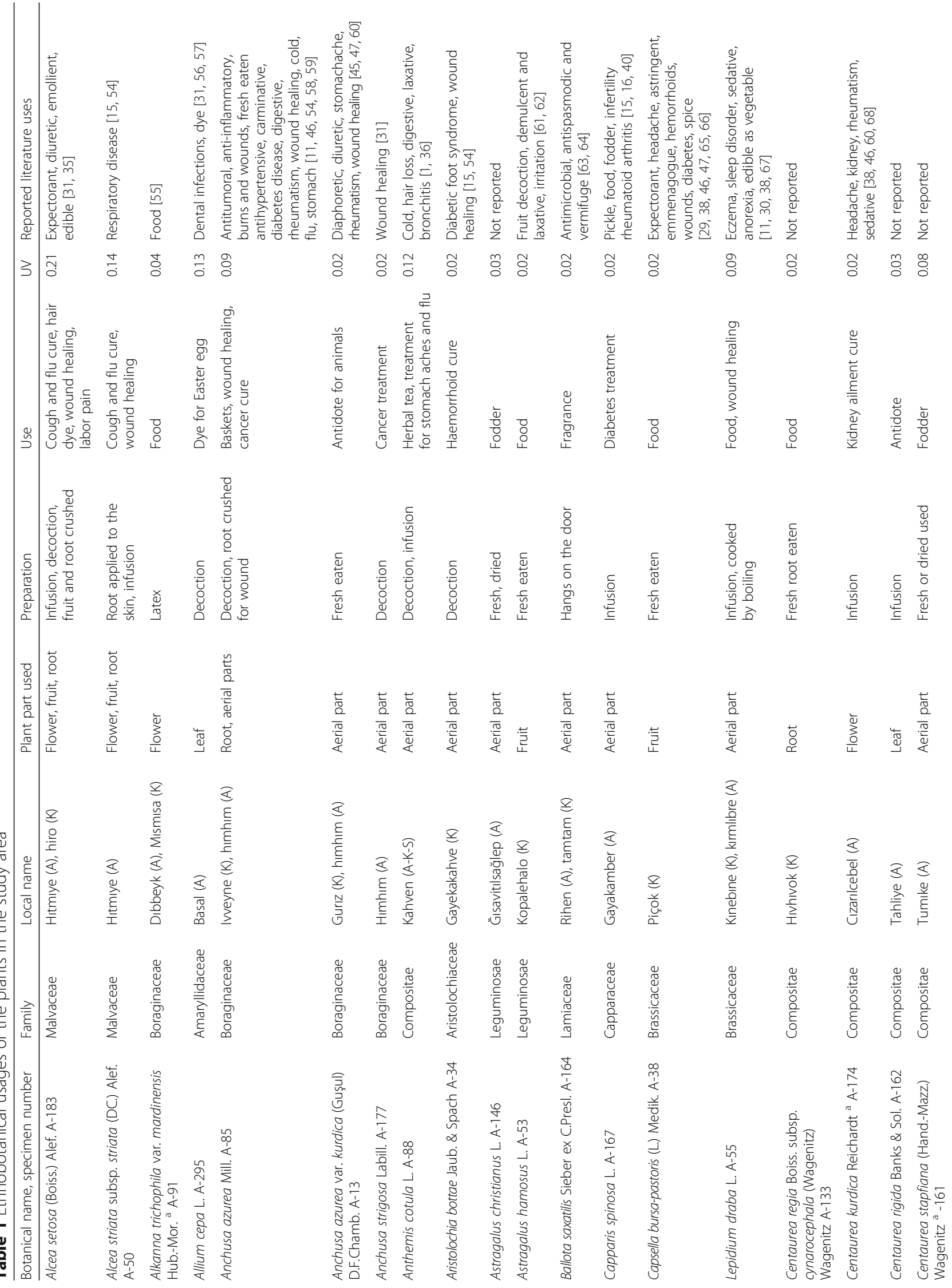




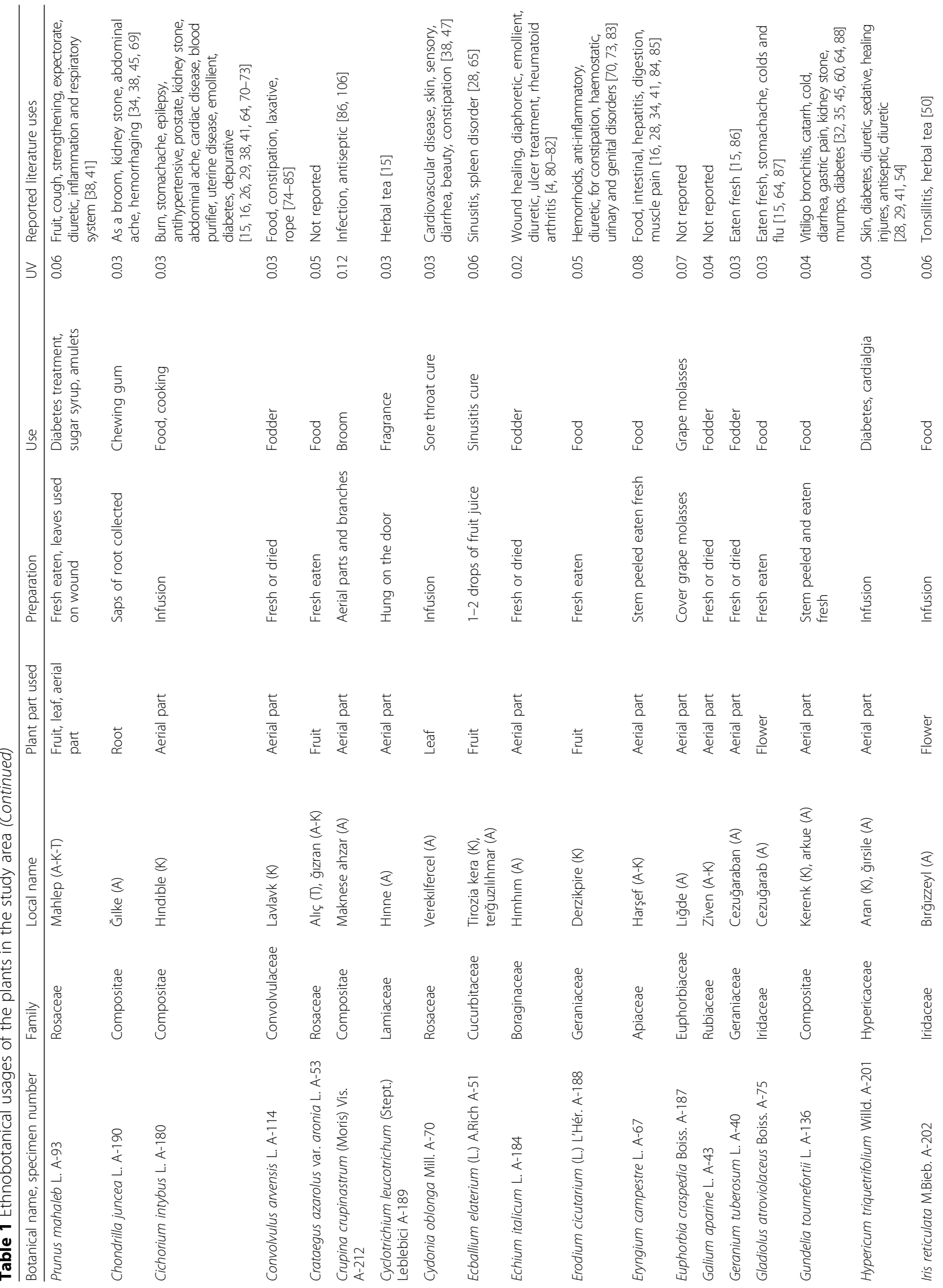




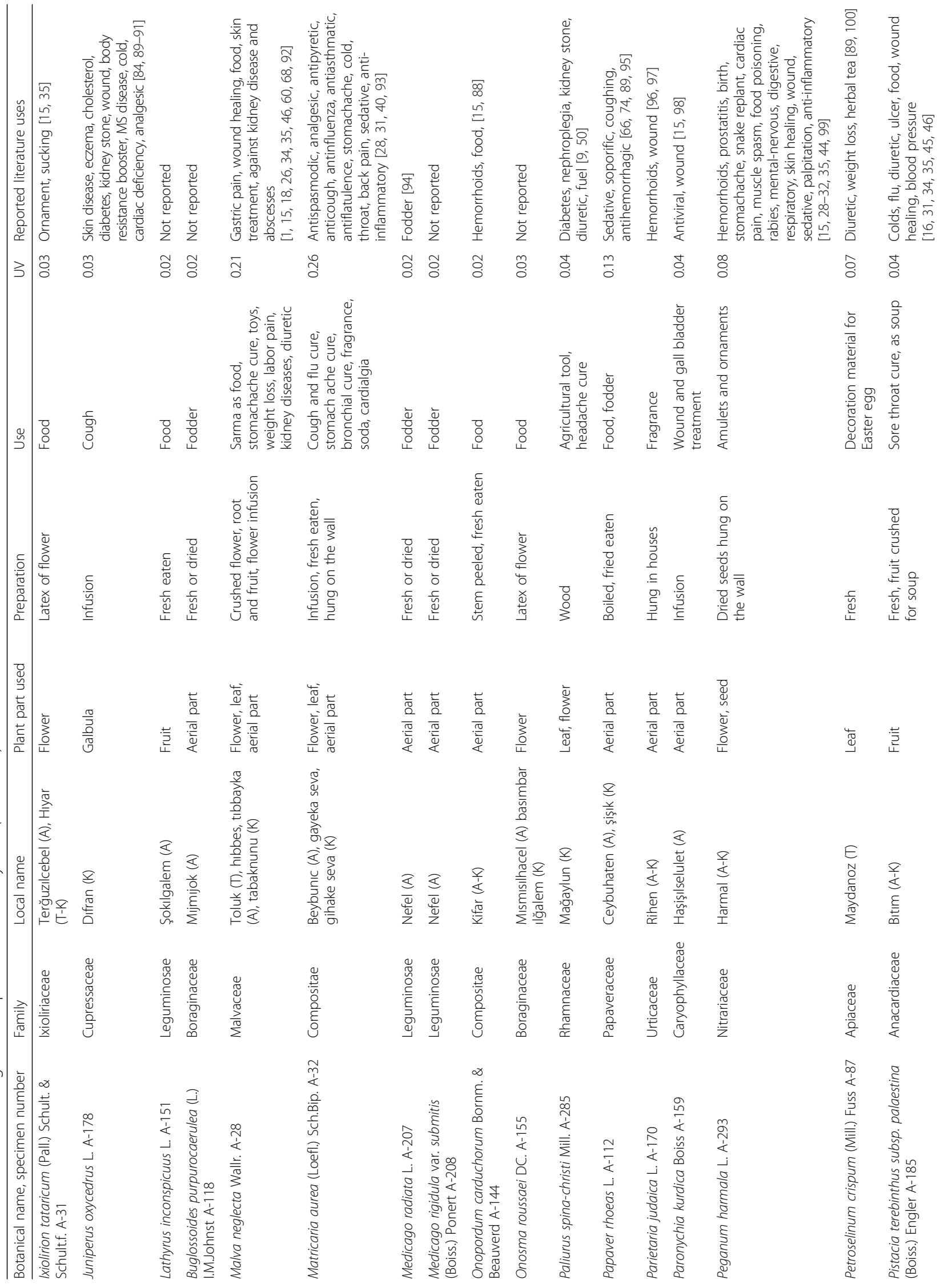




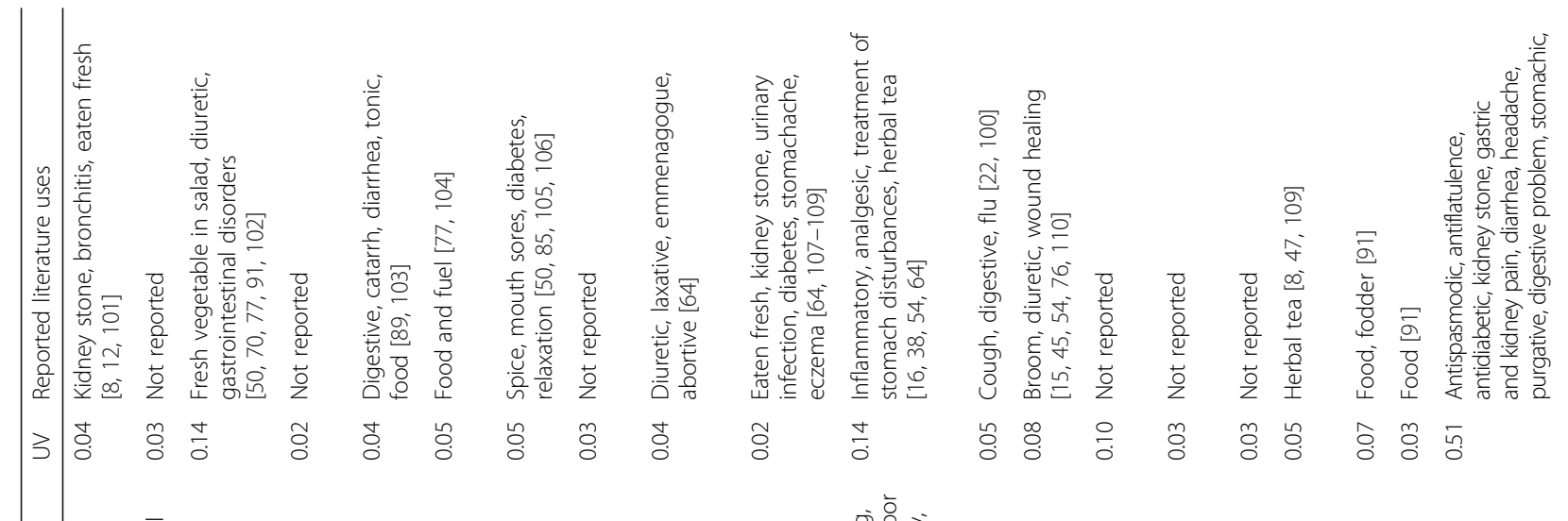

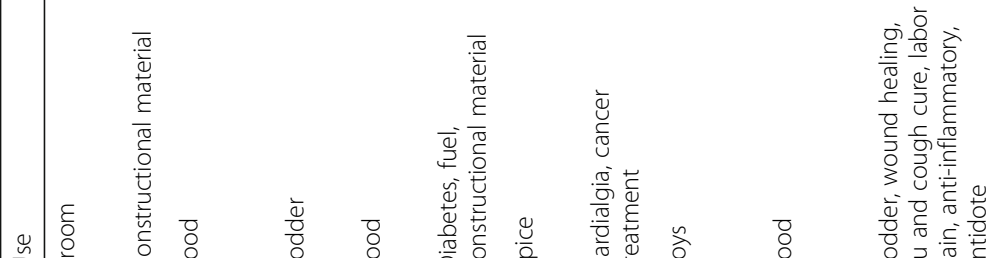

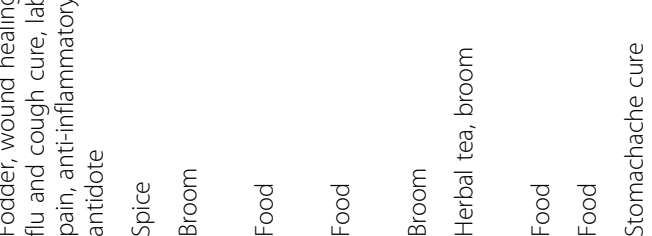

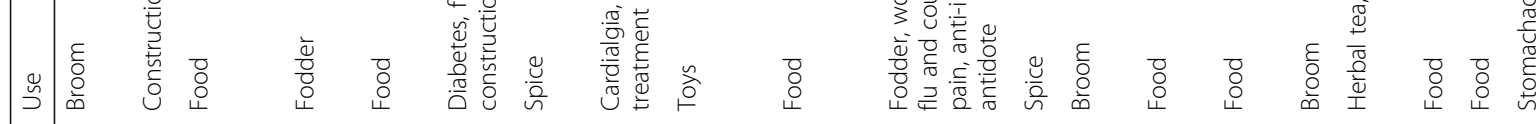

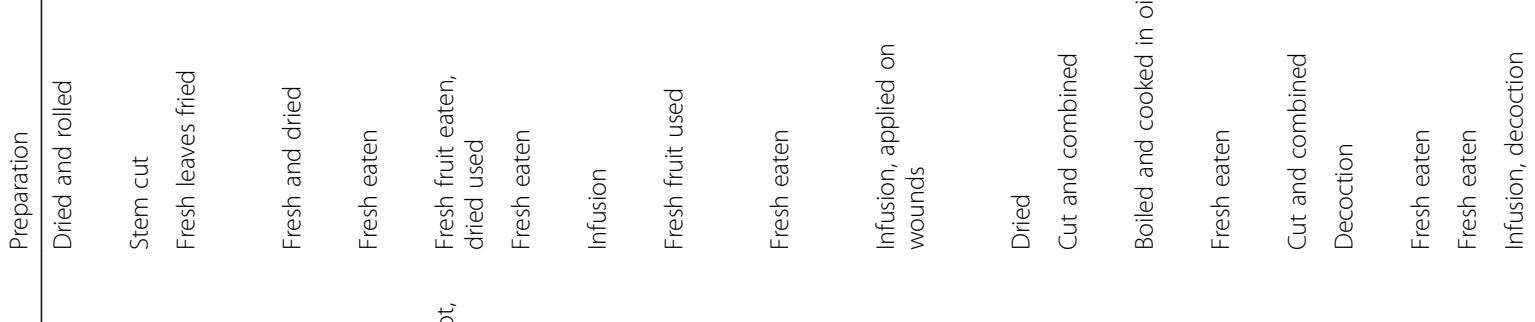

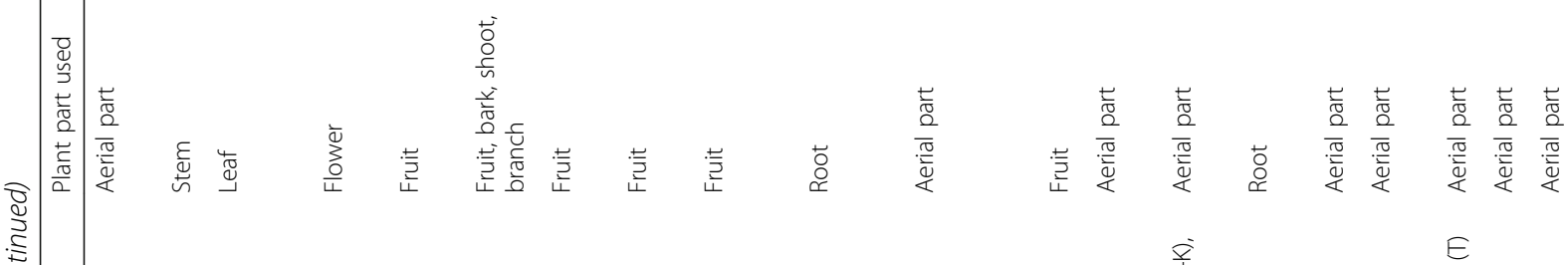

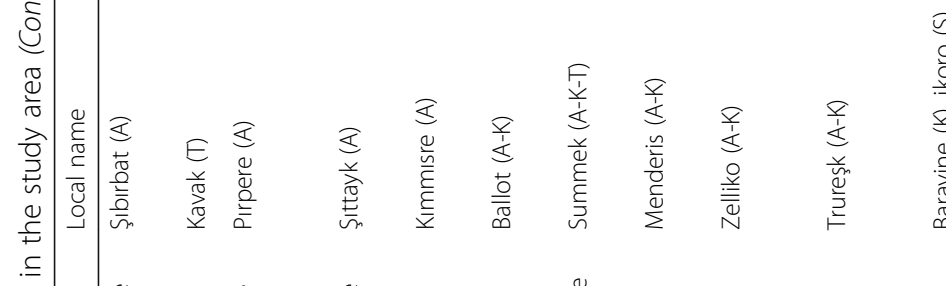

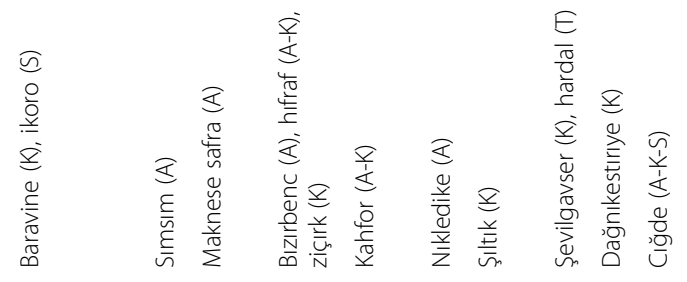

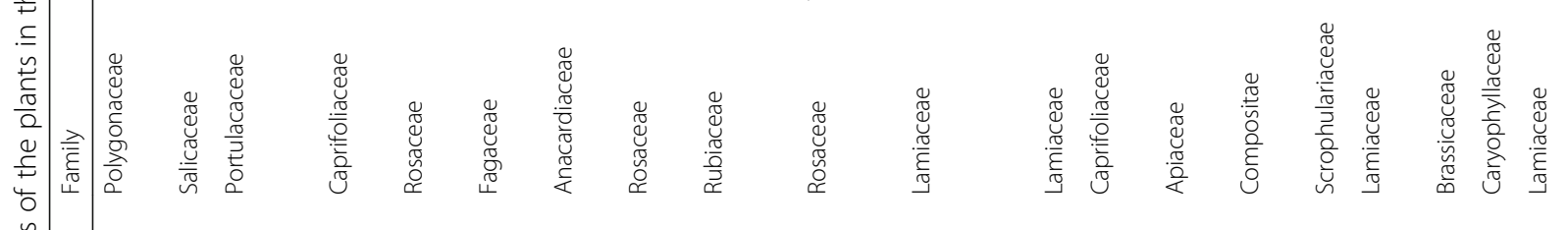




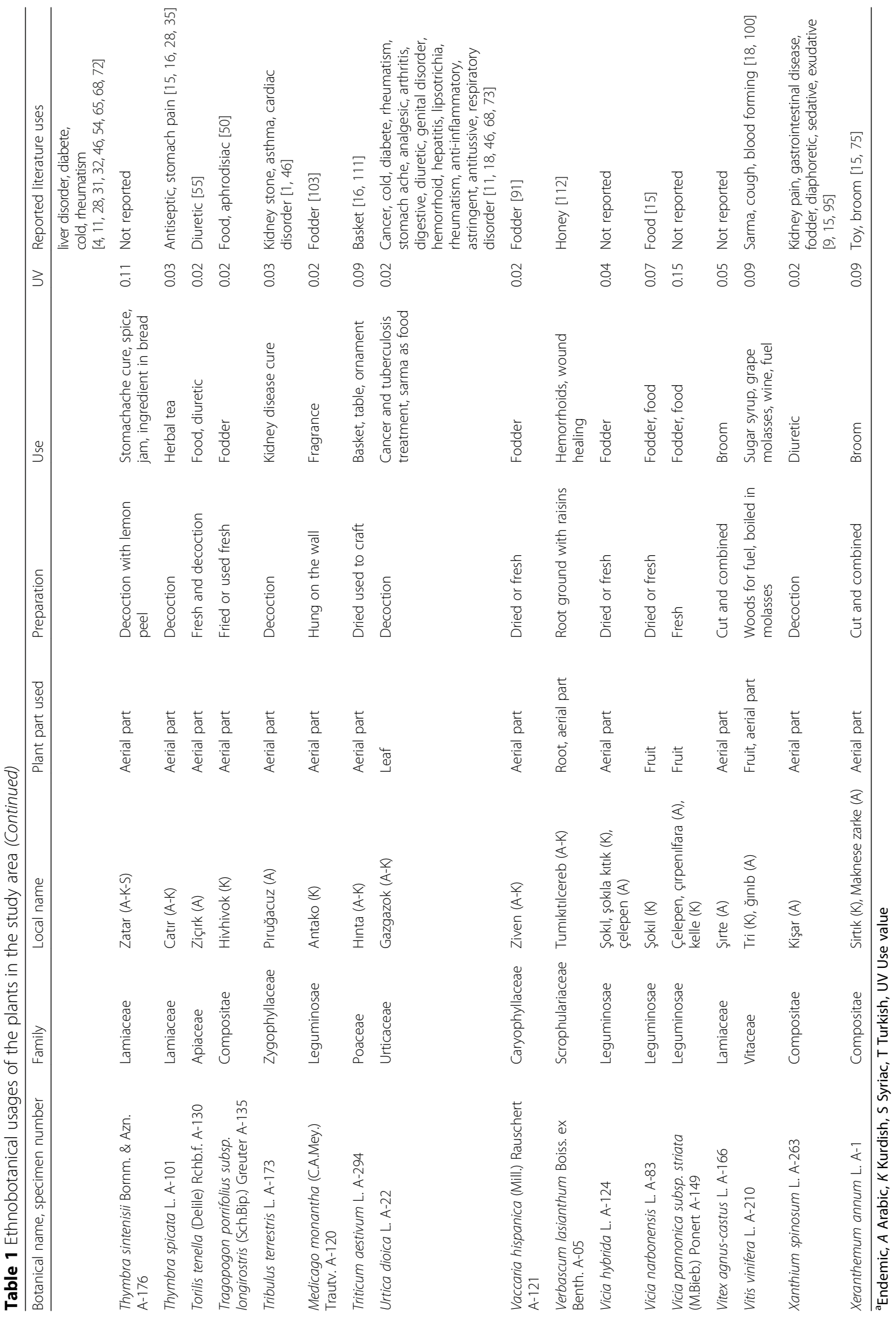


assisted us in obtaining information from local people. The International Society of Ethnobiology Code of Ethics was taken into account in interviews [24].

\section{Demographic characteristics of study participants}

We conducted face-to-face interviews and surveyed a variety of different participants. We identified and recorded demographic characteristics. We interviewed 123 persons, of which more than $70 \%$ were older than 55 years; the mean respondent age was 64 (Table 2). $66 \%$ of the participants were male, while female participants made up $34 \%$ of the survey.

The demographical characteristics of individuals are illustrated in Table 2. During the interviews, we consulted at least one person who could speak the local language and had a connection with local people. Since the research area was not a secure region, we also had permission from local police officers.

\section{Quantitative method for analysis}

We conducted our study by use value method [25], a quantitative method that demonstrates the relative importance of locally known taxa. It was calculated according to the following formula: Use value (UV), a quantitative method that demonstrates the relative importance of plant species known locally, was also evaluated according to the following formula [26]:

$$
\mathrm{UVi}=\sum \mathrm{Ui} / \mathrm{Ni}
$$

where UVi refers to the use value of a species, Ui to the number of citations per specific plant species, and $\mathrm{Ni}$ to the number of informants. A high UV indicates the potential importance of the plant species reported.

\section{Results and discussion}

The focus of the study was to identify wild plants, instead of agricultural plants, with medicinal usages. This study will fill a gap in the knowledge about different usages of endemic and rare plants. In this study, Midyat was selected because of the mixed cultures and the fact

Table 2 Demographic details of the interviewed informants

\begin{tabular}{lll}
\hline Category & Subcategory & \% of informants \\
\hline Gender & Male & 34.2 \\
& Female & 65.8 \\
Age & $20-40$ & 9 \\
& $40-60$ & 51 \\
& 60 and older & 40 \\
Education level & None & 35 \\
& Primary & 59.5 \\
& Secondary & 5.5 \\
\hline
\end{tabular}

that no ethnobotanical or floristic studies had been conducted in this region. We focus on: 1) identifying medicinal plant usages 2) determining new ethnobotanical usages and evaluating our findings in terms of cultural ethnobotany.

In the course of this study, we collected 368 voucher specimens in the investigated area. According to identification results, 92 were traditional plants (81 wild taxa and 11 cultivated plant taxa) (Table 1). Most respondents stated that they had learned the ethnobotanical uses of plants from their parents and elderly relatives. Wild-growing plants were not considered as holding the same economic value as cultivated plants in the studied area. Among the 92 taxa of traditional plants (129 plant usages), 35\% were used for medical purposes, $22 \%$ for food, $13 \%$ for animal fodder, $7 \%$ as ornaments and dyes, $6 \%$ for broom production, $4 \%$ for latex and as fragrance, $4 \%$ for herbal tea, molasses and wine preparation, $3 \%$ for agricultural purposes, and 6\% were used for different purposes (Fig. 2). Within the observed taxa, 21 new ethnobotanical usages were determined in this study.

Local people use various parts of the plants in the region. Of the 92 identified plant taxa, $49 \%$ are used for their aerial parts, $20 \%$ for their fruits, $9 \%$ for their flowers, and $15 \%$ for their leaves, stem and roots; in 7\%, other parts are used. We compared our findings with previous ethnobotanical studies in Turkey and other countries (Table 1). Our study indicates the importance to document not only medicinal plants, but also edible plants or plants used for fodder, fuel, dyes, and other purposes. In our study, specific and interesting plant usages were determined, such as using the whole of an endemic plant as a broom, herbal tea against cold, or painting Easter eggs with plant dyes. The conservation of this extensive knowledge is crucial, particularly because knowledge is no longer being passed down from older to younger generations.

\section{Highly utilized species}

Use value (UV) is a very important tool for demonstrating the relative importance of medicinal plants in the designated area. Based on our analyses, UV ranges from 0.10 to 0.20 reveal the common ethnobotanical usages for the following taxa: Anthemis cotula (0.12), Allium cepa (0.13), Alcea striata subsp. striata (0.14), Crupina crupinastrum (0.12), Papaver rhoeas (0.13), Salvia multicaulis (0.14), Thymbra spicata (0.11), and Vicia pannonica subsp. striata (0.15). The highest UVs are recorded for Teucrium polium (0.51), Matricaria aurea (0.26), Alcea setosa (0.21), and Malva neglecta (0.21) (Fig. 3, Table 3).

Especially in villages of Midyat, people can easily find highly utilized species. The villagers always keep a dried flowers and plant materials for medical usages or food additives. As an example, Teucrium polium, Matricaria aurea, and Alcea setosa are always presents in many houses in Midyat. Especially, Teucrium polium is a well-known 


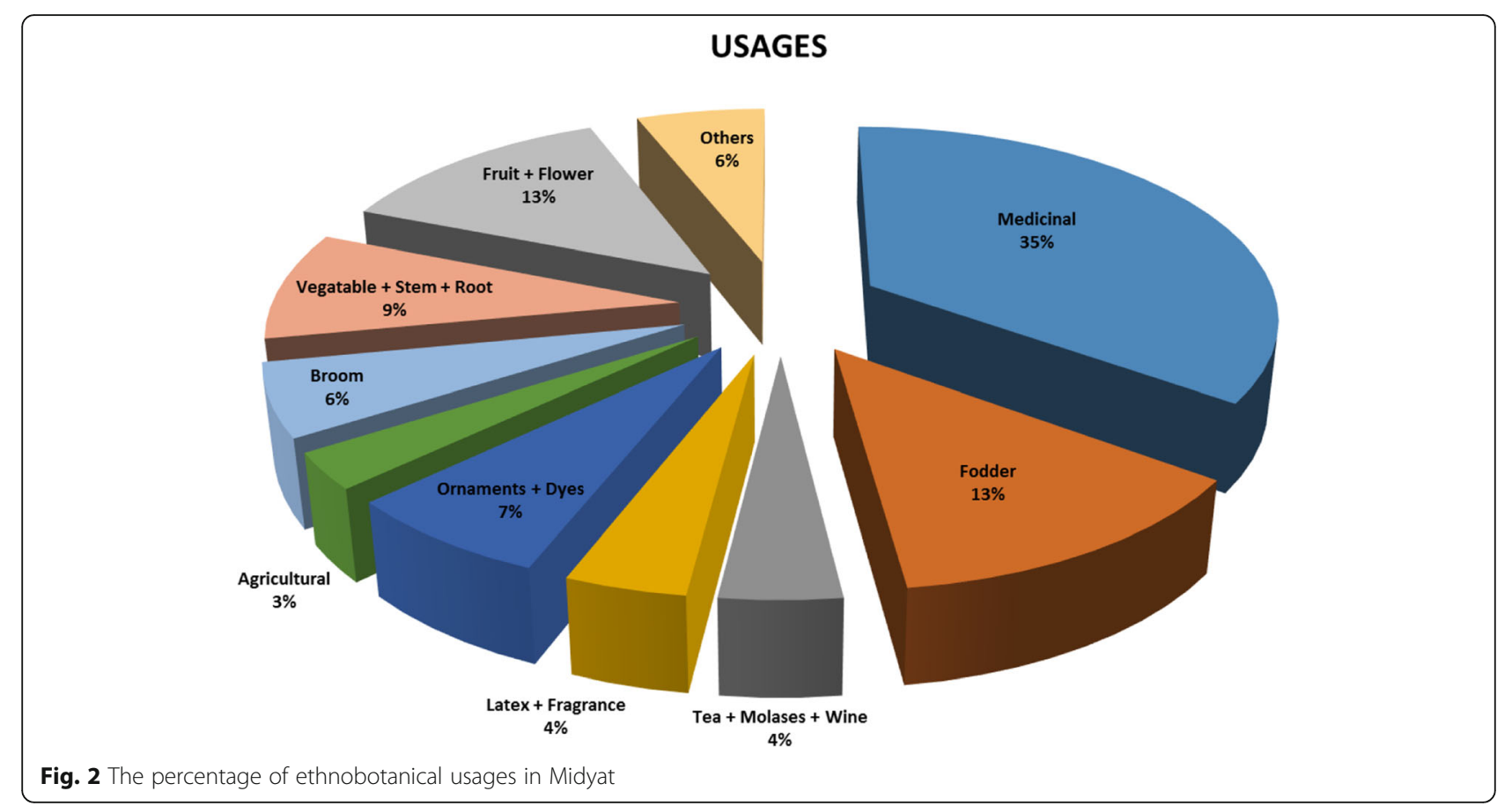

remedy in the region, and the dried plant can be found also in local sellers in the city center. Moreover, several other ethnobotanical usages such as soups, ornaments, and fresh plants can be found in local stores in Midyat. Most of plant species that have high UVs can be grown easily such as Matricaria aurea, Alcea setosa, and Malva neglecta. Animal fodders are also common usages in the region because they have grown easily and collected by several villagers in Midyat.

Some highly utilized plant species have already been investigated in terms of biological and chemical properties. For example, Teucrium polium has a wide range of applications in the region; owing to unique phytochemicals with new biological activities, more than 130 compounds have been identified so far, and it is used as an antiinflammatory, antinociceptive, antispasmodic, anticancer, antimutagenic, hypoglycemic, hypolipidemic, hypotensive, anti-ulcer, and antimicrobial [27]. In our study, aerial parts of Teucrium polium are used mainly against stomachaches

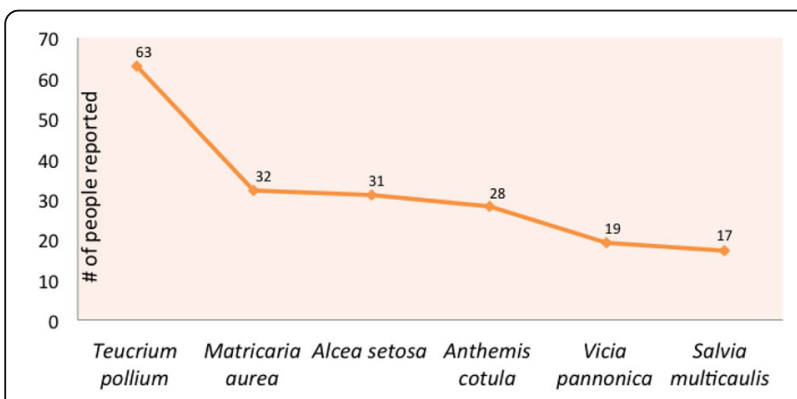

Fig. 3 Most common plant usages in Midyat and stomach pains in humans and also animals. Other reported uses of this species are to combat diabetes, diarrhea, and rheumatoid arthritis in Gaziantep [28]; for digestion in Egypt; as food in Albania and Algeria [29]; for liver diseases in Iran [30]; for diabetes and kidney issues in Jordan [31]; and for diarrhea and hemorrhoids in eastern Turkey [32]. Interestingly, the authors were warned that extended use of Teucrium polium could cause adverse effects in the liver and kidney [27]. In our study area, there is a very intense usage of Teucrium polium, and local people need to be aware of the potential adverse effects of these usages.

Matricaria aurea's essential oils are very rich in chemical compounds, such as phenolic coumarin, which contribute to a moderate antioxidant and antibacterial activity [33]. Matricaria aurea has seven different usages: for cough, flu, bronchial complaints, stomachache, cardialgia, as a soda, food, and fragrance. It is mainly used to treat stomachaches and colds by consuming it as an herbal tea. It was reported in previous studies carried out in Jordan that it is used to treat throat and back pains and high blood pressure in children, as a sedative, and an anti-inflammatory substance [31]. Alcea setosa (UV 0.21) is traditionally used as a pain reliever, a healing agent, and to treat coughs. Alcea setosa is reported for anti-inflammatory treatment of asthma in Jordan with UV 0.11 [31], and the leaves of plant are expectorative and diuretic [14]. The flowers and fruits of Alcea striata subsp. striata are used as hair dye and in beauty products in Midyat. The same taxon is also used to heal respiratory system disease in Şanlıurfa with a similarly high UV 0.12 [15]. Malva 
Table 3 A Important plant usages with preparation and application methods in Midyat 724. B Endemic plants usages in Midyat

\begin{tabular}{|c|c|c|}
\hline Plant scientific name & Aims of plant usage & Preparation and application \\
\hline \multicolumn{3}{|l|}{ A } \\
\hline \multirow[t]{4}{*}{ Alcea setosa } & Cough and flu & A handful of dry flowers are boiled and drunk during the sickness. \\
\hline & Hair care dye & The dried fruits are beaten or the flowers applied to wet hair. \\
\hline & Wound healing & $\begin{array}{l}\text { The seeds crushed and applied to the wounds to completely cover it to extract the } \\
\text { inflammation. }\end{array}$ \\
\hline & Labor pain & A handful of flowers of plant mixed with Mentha and boiled. \\
\hline \multirow[t]{2}{*}{ Alcea striata subsp. striata } & Cough and flu & During flu, the flowers of the plant are boiled and brewed as herbal tea. \\
\hline & Wound healing & $\begin{array}{l}\text { The crushed seeds used to cover the wound area completely in order to extract the } \\
\text { inflammation. }\end{array}$ \\
\hline \multirow[t]{2}{*}{ Anthemis cotula } & Stomach pain & $\begin{array}{l}\text { Leaves of plant are boiled and used as an herbal tea to treat cold, bronchitis, flu, and } \\
\text { stomachache. }\end{array}$ \\
\hline & Flu and cold & Herbal tea brewed for cold and flu treatments. \\
\hline Crupina crupinastrum & Broom & Aerial parts and branches used for making broom. \\
\hline \multirow[t]{5}{*}{ Malva neglecta } & Food & Fresh aerial parts collected and boiled in water and then fried in oil and mixed with eggs. \\
\hline & Stomachache & A couple of fresh leaves used in the morning on an empty stomach. \\
\hline & Toys & Children use their fruit seeds as a toy like marbles. \\
\hline & Against weakness & $\begin{array}{l}\text { When people are critically weak, they have the fresh leaves by adding salt and boiling } \\
\text { them. The brew is taken until the patient feels better. }\end{array}$ \\
\hline & Labor pain, kidney diseases & $\begin{array}{l}\text { Pregnant used by boiling the leaves of the plant. For kidney stones used by boiling the } \\
\text { leaves and drinking it like an herbal tea. }\end{array}$ \\
\hline \multirow[t]{3}{*}{ Matricaria aurea } & $\begin{array}{l}\text { Cough, flu, bronchial, } \\
\text { stomach cure, cardialgia }\end{array}$ & The plant is boiled and drunk for treatment. \\
\hline & Food & After the fruit and leaves are washed, they are consumed as a food. \\
\hline & Fragrance & The whole plants hang on the walls in the entrance of houses to give a good smell. \\
\hline \multirow[t]{2}{*}{ Papaver rhoeas } & Food & $\begin{array}{l}\text { Fresh young leaves used by boiling and frying for eating. Their flower is added to boiled } \\
\text { pounded wheat (bulgur pilav). }\end{array}$ \\
\hline & Fodder & For feeding animals; dry and fresh plants used. \\
\hline \multirow[t]{5}{*}{ Salvia multicaulis } & Wound healing & $\begin{array}{l}\text { After boiling, it is applied to wounds by mixing it with vetch; it is applied at night and } \\
\text { kept bandaged until morning. }\end{array}$ \\
\hline & Flu and coughs & It is mixed with Imtabso (Papaver) and boiled with some water and is taken. \\
\hline & Labor pain & $\begin{array}{l}\text { The aerial part of plant used as an herbal tea; it is brewed and filtered. People drink it for } \\
\text { treatment of labor pain. }\end{array}$ \\
\hline & Anti-inflammatory & $\begin{array}{l}\text { It is used to treat wounds such as warts and boils; to take out the inflammation, the Plant } \\
\text { is boiled and applied on hands at night, kept covered until morning. }\end{array}$ \\
\hline & Antidote & $\begin{array}{l}\text { It is used when a scorpion bites; plants boiled and the water applied to the bite region } \\
\text { and held with bandages. }\end{array}$ \\
\hline Scandix stellata & Food & The leaves of plant fried and cooked with oil. \\
\hline Teucrium polium & Stomachache & It is brewed for use against stomach pain for children, adults and sometimes for animals. \\
\hline \multirow[t]{3}{*}{ Thymbra sintenisii } & Labor pain & Plant used as an herbal tea. It is brewed adding lemon peel and used for labor pain. \\
\hline & Spice & Used as spice by adding it to salads and dishes. \\
\hline & Bread preparation & $\begin{array}{l}\text { It is also used in preparation of bread; it is mixed with almond and watermelon peel, } \\
\text { then fried in olive oil and cooked in a tandoor (oven consisting of a clay-lined large pit). }\end{array}$ \\
\hline \multirow{2}{*}{$\begin{array}{l}\text { Vicia pannonica subsp. } \\
\text { striata }\end{array}$} & Food & The fresh fruit consumed by people by peeling. \\
\hline & Fodder & For feeding animals whole fruits are used fresh or dried. \\
\hline Centaurea rigida & Antidote & $\begin{array}{l}\text { It is used when a scorpion or a snake bites; plant is boiled and the water applied to the } \\
\text { bitten region. The treatment continues until healed. }\end{array}$ \\
\hline Euphorbia craspedia & Molasses preparation & $\begin{array}{l}\text { The aerial part of plant is used while boiling the molasses; the plant prevents overflow. } \\
\text { The whole plant covers the pan for that purpose. }\end{array}$ \\
\hline
\end{tabular}


Table 3 A Important plant usages with preparation and application methods in Midyat 724. B Endemic plants usages in Midyat (Continued)

\begin{tabular}{lll}
\hline Plant scientific name & Aims of plant usage & Preparation and application \\
\hline B & & \\
$\begin{array}{l}\text { Alkanna trichophila var. } \\
\text { mardinensis }\end{array}$ & Latex & Latex of flower is used to suck for children. \\
$\begin{array}{l}\text { Centaurea kurdica } \\
\text { Centaurea stapfiana }\end{array}$ & Kidney disease & The fruit of plant is used after boiling in water; used as a drink. \\
Sideritis libanotica subsp. & Herbal tea & Dried or fresh aerial part of plant is used for feeding animals intensively in the region. \\
linearis & Broom & The plant is used for brewing and drinking in cold weather. \\
& & Whole plant used as a broom. \\
\hline
\end{tabular}

neglecta has UV 0.21, and six different usages are reported in Midyat. It is used as a food, against stomachache, for children's toys, in order to lose weight, against labor pain, kidney diseases, as a diuretic, and to make traditional rolling leaves with rice, called sarma. Several studies reported its use as food [15, 34] and as skin ointment [15, 32]. Malva neglecta is used to heal kidney diseases, and in another study from eastern Turkey, the use of this plant to treat abscesses was also reported [35].

In the current study, Anthemis cotula is used for several purposes, such as for treating colds by brewing it as an herbal tea, against bronchitis, as a hair treatment, and as a treatment for flu and stomachaches in Midyat. Some similar usages of Anthemis cotula are reported for treating colds, hair loss and bronchitis [1, 36]. Salvia multicaulis has an interesting usage in the region: as an antidote against scorpion bites (Table 3). Salvia multicaulis is also used as an herbal tea in Midyat, Cizre, and in Elazı̆̆ $[16,37,38]$, and as a spice and to heal skin wounds in the southeast of Turkey [16, 39].

Previously we discussed the ethnobotanical usages with the highest UV value in Midyat. Some less common but no less interesting usages were also reported: Thymbra spicata is used in Midyat as an herbal tea for stomachaches. In addition, it is used as an antiseptic [35], as a spice [28], and the leaves of plant are also used in the process of making cheese [37] in southeast regions of Turkey. Capparis spinosa is used for diabetes treatment and as an ingredient in pickle. It is used as a pickle, food, and fodder in Şanlıurfa
$[15,16]$, and as a pain reliever and to treat rheumatoid arthritis in Jordan [40]. Lepidium draba is consumed as a food in Midyat. In Elazığ province, the fruits of this plant are used as a spice [40], and it is eaten fresh in Iran [30]. Fruits of Prunus mahaleb are consumed as a food and against coughing. It is used as a food in Agri [41], and the seeds of plant are used as an expectorative, diuretic substance, and to treat inflammation in Elazı̆g [38]. Centaurea kurdica is boiled in water and used for healing kidney disease. Moreover, the flowers are used as a sedative in Elazığ [38]. Chondrilla juncea is used as a gum in Elazığ [38], as a broom [42] and against stomachaches in eastern parts of Turkey [42]. Eryngium campestre are peeled and eaten in Midyat (Fig. 4). It is also used to treat intestinal disorders [28], flatulence, hepatitis [41], digestion disorders, and muscle pain [29]. Eryngium campestre is consumed as a food in neighboring cities such as Cizre [16]. An unusual ethnobotanical finding was uncovered that children suck the flowers of Ixiolirion tataricum in this study area. A similar usage is also reported in Birecik [15]. Peganum harmala is known as Syrian rue and Harmal. It has varying pharmacological functions such as analgesic, anti-inflammatory, antioxidant, leukemic, hypoglycemic, and antitumor effects [43]. Nevertheless, its notable usage is for protection against evil spirits in Midyat. The same usage is reported in the southeast of Turkey $[15,28,35]$. It is hung on the wall, especially for the protection of babies against evil spirit. This species is additionally reported for its use
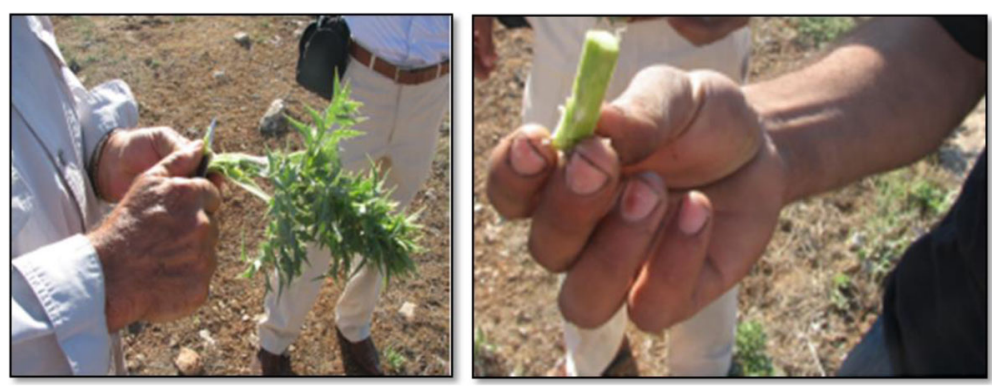

Fig. 4 Usage of Eryngium campestre by local people in Midyat 
against heart disease [28], rabies, snake bites, muscle spasms, and food poisoning [30]. Also, Peganum harmala aids in skin and wound healing, as a sedative, to treat inflammations, heart palpitations, nervous system and digestion problems [29, 31]. The seeds of the plant are mixed with honey and used to treat stomach pains [32], and its red fruits used to produce dye in eastern Anatolia [44]. Pistacia terebinthus subsp. palaestina has several different usages in the southeast of Turkey. We found that local people make soup with the plant in Midyat (Fig. 5a), and fresh shoots are eaten to treat stomachache. It is similarly used to make soup in neighboring cities [16], and it heals wounds in Malatya [45], where it is also reported as an ulcer treatment [46]. It is an antiseptic and diuretic, used to reduce fever and high blood pressure and to heal ulcers [31]. The young flowers and fruits are consumed against colds and as diuretic agents and its usage as resin, antimicrobial substances and glue have been reported in eastern Turkey [42].

In the region, utilizing plants as brooms was a common ethnobotanical usage. Scabiosa argentea is used as a broom (Fig. 6a), and the same usage was reported previously in Şanlıurfa and Birecik [15]. Residents of Midyat use Sideritis libanotica subsp. linearis as a broom and herbal tea. Sideritis libanotica was previously also reported as a broom in eastern Turkey [47]. Additionally, Xeranthemum annum is used as a broom in Midyat (Fig. 6a). The $X$. annum was similarly used as a broom in Sanliurfa [15]. Sideritis libanotica subsp. linearis is also used in the region as a broom by using the aerial part of the plant.

Some other interesting wood products were found in the region, such as colorful trays and ornaments. As an example, Triticum aestivum is used for the production of traditional carrying trays (Fig. 6b). Similar usage of tray-making was determined in Cizre (Şırnak) [16]. Vitis vinifera and Quercus brantii are commonly used as fuel, and dried branches of these plants are stored on almost all houses in the villages (Fig. 7). People in the region consume many local plants, and sellers use this to their advantage by promoting the locality of the products in Midyat. As an example, stems of Gundelia tournefortii are peeled and eaten fresh, and then sold by local people (Fig. 5b).

In our study area, perhaps the most picturesque ethnobotanical usage is Easter eggs (Fig. 8a-b). They are prepared at Easter by local Christians called Syriacs. First, wet parsley leaves (Petroselinum crispum) were fixed to the egg, and the eggs are boiled slowly with red onion peels (Allium cepa) in a pan. After removing the parsley, the Easter eggs are ready (Fig. 8d). In Turkey,

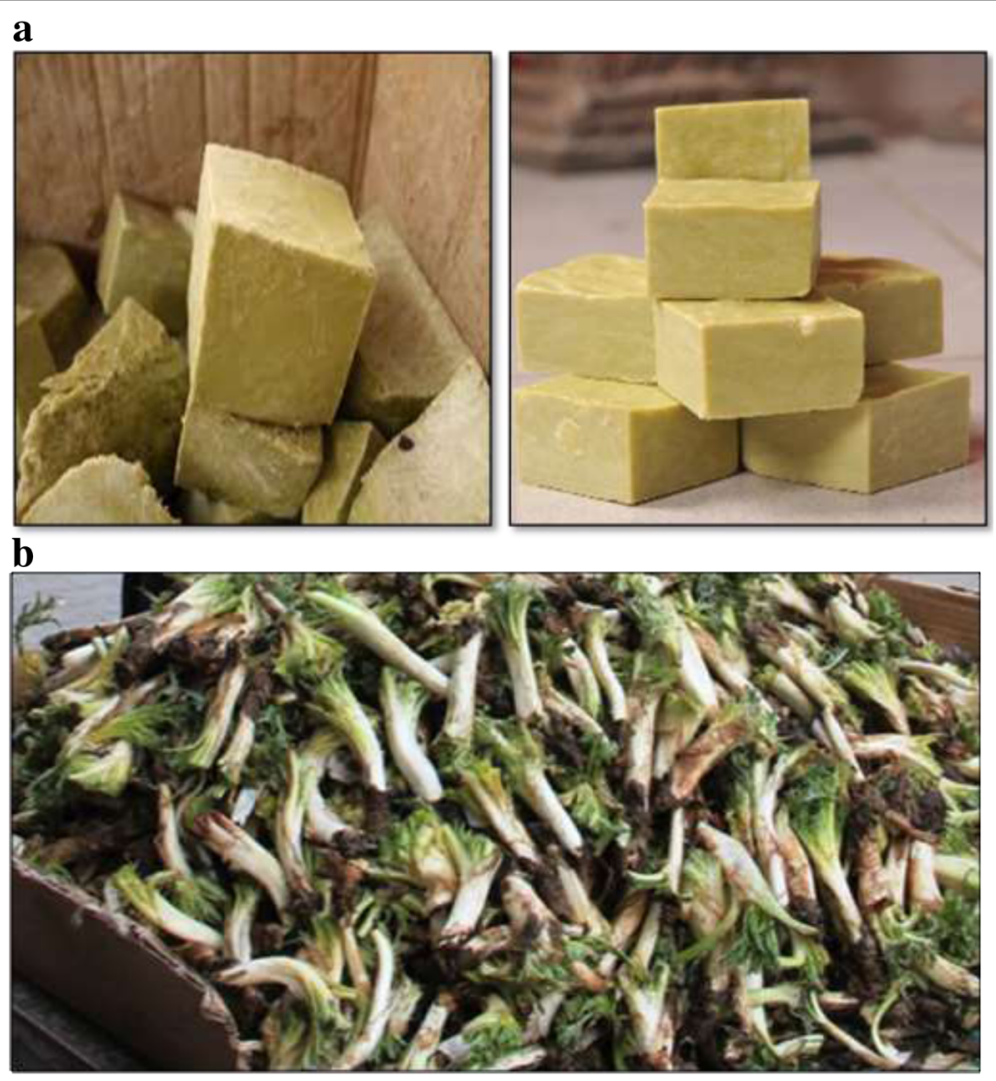

Fig. 5 a. Bitim soup Pistacia terebinthus subsp. palaestina and b. Gundelia tournefortii sold in local markets 

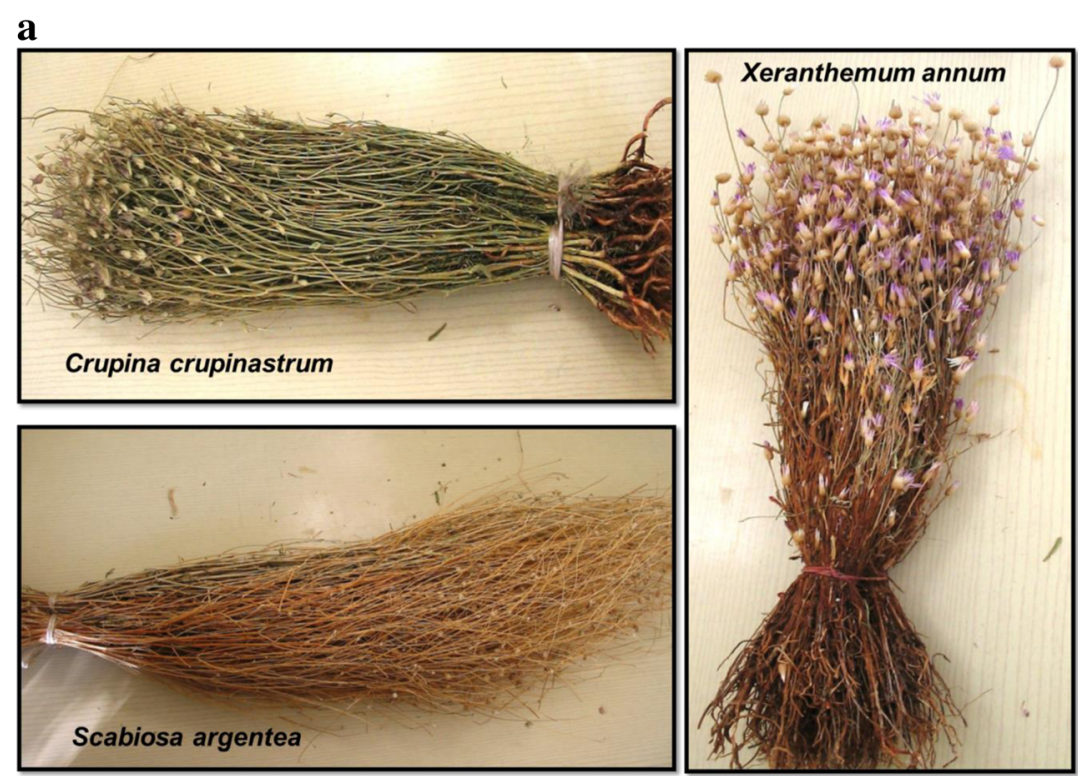

b

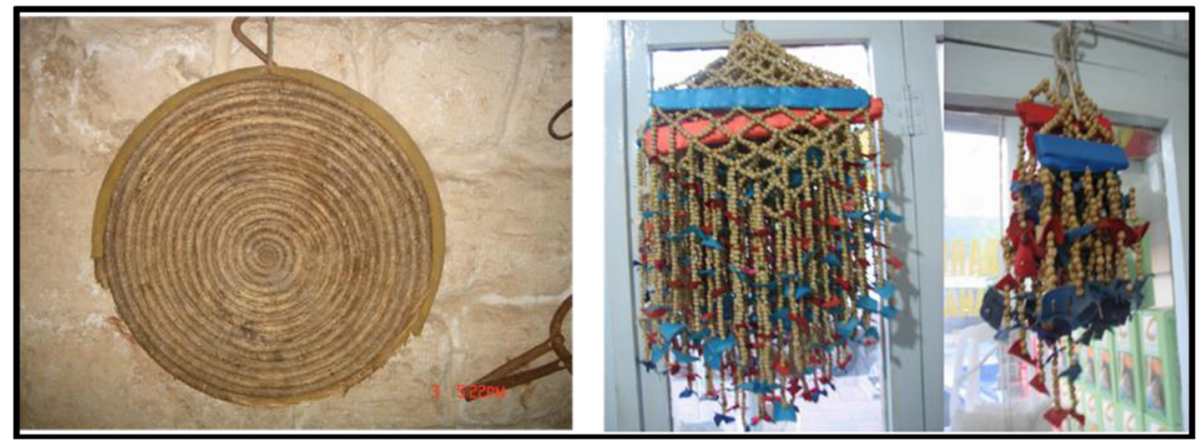

Fig. 6 Some interesting usages: a. Brooms from Midyat. b. Usages of Peganum harmala (nazarlik) and Triticum aestivum (tray)

you can see some egg painting in large cities such as Izmir. Local sellers sell these eggs, and people like to buy them because of the attractive shapes.

The following plants are used as fragrance at the entrance of houses or on top of front doors: Ballota saxatilis, Cyclotrichium leucotrichum, Matricaria aurea, Parietaria judaica, Trigonella monantha. Additionally, fruits of Peganum harmala and Prunus mahaleb are used as ornaments called 'nazarllk' against bad spirits, commonly in the southeast of Turkey (Fig. 6b). Euphorbia craspedia is locally used to clean the thick bubble layer on grape molasses. Fruits of Malva neglecta and Rubia tenuifolia

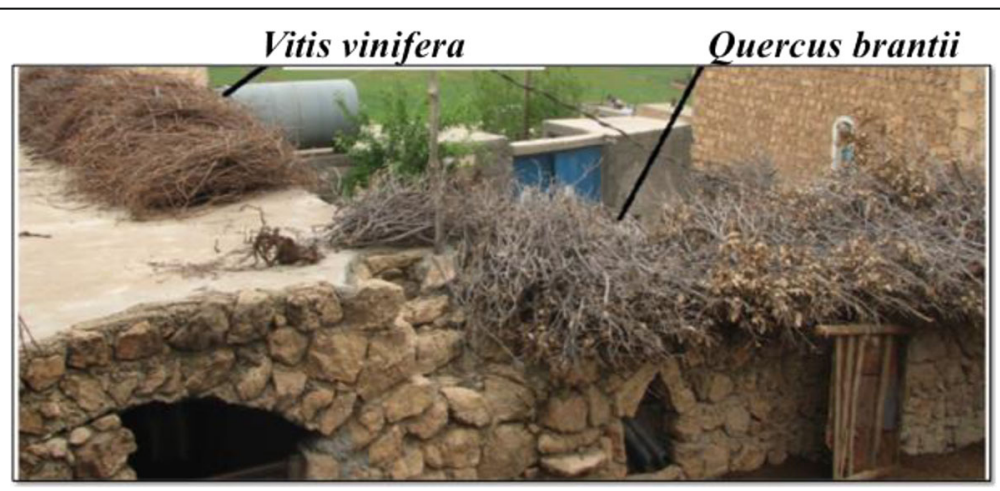

Fig. 7 Fuel plants Vitis vinifera and Quercus brantii stored on the stone houses in Midyat 

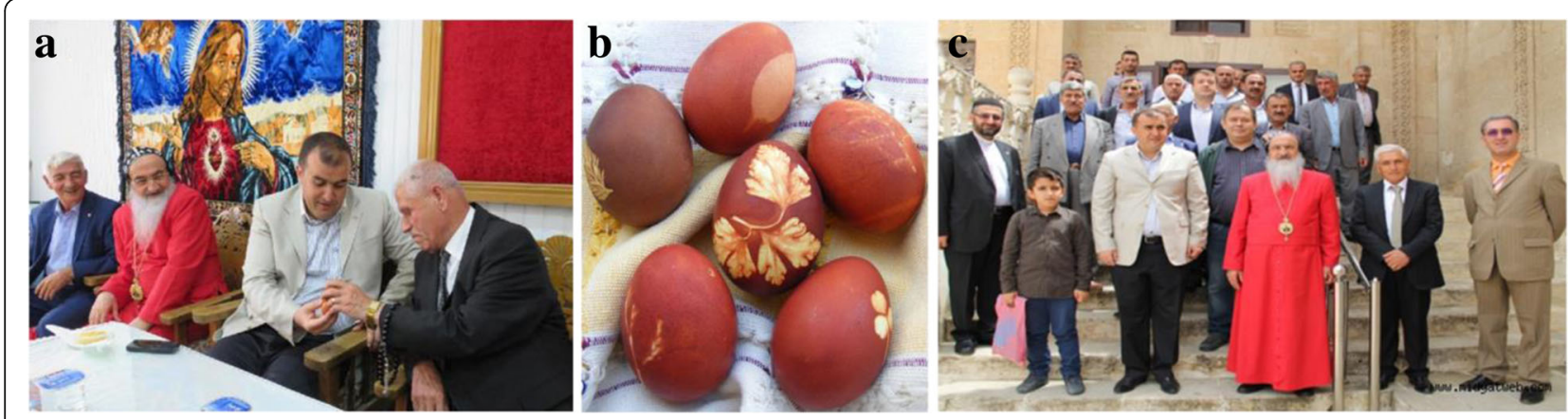

Fig. 8 Traditional usages of Allium cepa in Midyat. a. Government officials celebrate the Easter ceremony by sharing eggs in Midyat [53]. b. Dyed Easter eggs by red onion after decorated with parsley leaves. c. Local people, religious leaders (pastor and imam) as well as government officials come together in an Easter ceremony by sharing eggs in Midyat [53]. Note: A copyright permission was obtained by copyright holder, Dogus Ofset Gazete ve Matbaacilik

subsp. donietti are used as children's toys in Mardin, and the people of Mardin consume the flowers of Alkanna trichophila var. mardinensis.

Some plants have not previously been reported; these endemic plants are represented in Table 3. Their method of preparation and application are detailed. Four endemic plants were reported (Table 3), Alkanna trichophila var. mardinensis (Boraginaceae), Centaurea kurdica (Asteraceae), Centaurea stapfiana (Asteraceae), and Sideritis libanotica subsp. linearis (Lamiaceae). These plants are used extensively; for example, Centaurea stapfiana is used as fodder for animals. This negatively impacts on the conservation of these plants in the region, and there is an issue trying to protect this species as it can only be found in Midyat. Another species, Centaurea kurdica, is only traditionally used for healing urinary problems and therefore not as endangered as the previous two species. Alkanna trichophila var. mardinensis is locally used by children, who consume the flower latex; it is, however, not extensively used and therefore not in danger. Sideritis libanotica subsp. linearis, whose leaves are used to brew an herbal, and which are also used as brooms, is not a common plant usage, and found in limited locations. The location of Sideritis libanotica makes it challenging to collect because it grows in mountains and in shrubs. Thymbra sintenisii is used as an herbal tea and spice in Icoren villages. It is a very rare plant and can only be found in two places in Turkey, and construction of highways could badly affect populations of this plant. Even though it is not an endemic species, it has a potential for protection in terms of its pharmaceutical features.

Additionally, we observed many similarities between the names of cultured plants from Midyat and those from bordering countries. These findings show a possible relationship between Jordan and Midyat-Batman in terms of migration and languages. We found similar plant names in Midyat and Jordan for seven species [31]: Alcea setosa, Allium cepa, Anchusa strigosa, Pistacia terebinthus subsp. palaestina, Matricaria aurea, Peganum harmala and Teucrium polium. We already know that the common language of the two regions is Arabic. We also compared some of our findings with other studies conducted in bordering countries. For example, Bulgarian-Turk immigrated communities showed more overlapping species among medicinal plants than edible plants in the border regions [48]. In our study, medicinal usages overlapped among different communities. Border regions are important for cross-cultural and cross-border ethnobotany in order to determine changes and variability of medical plant uses and heritage [49]. Even though the region is not very stable right now, an extended study that focuses on cross-border ethnobotany in Turkey, Syria, Iraq, and Iran is needed in future. This is because in the region, only a limited number of ethnobotanical studies have been carried out [15, 16, 50-52].

\section{Conclusion}

Midyat is a city on the Silk Road, which has welcomed very different cultures and religions for thousands of years. The people of Midyat have lived in peace because of their respect and tolerance to others. Even though people in this region have different backgrounds of religion and culture, they have similar botanical knowledge. Other than red peels of Allium cepa, which are used for painting Easter eggs, they do not have many distinct differences. This type of study will certainly help to uncover, protect, and pass to the next generation the rich cultures of Midyat. The people in Midyat and nearby villages still trust traditional medicine, so in Midyat and its vicinity people continue to use traditional medicines. Our study indicates the importance to document not only medicinal plants, but also edible plants or plants used for fodder, fuel, dyes, and other purposes. We determined the highest UVs for Teucrium polium (0.51) and Matricaria aurea (0.26); further pharmacological study needs to be done for these species. The conservation of this extensive knowledge is 
crucial, particularly because knowledge is no longer being passed down from older to younger generations. The use of endemic plants is relatively rare, but Centaurea stapfiana, Thymbra sintenisii are used extensively, and their conservation status is compromised by their use as food and fodder plants. Additionally, our findings suggested that Midyat and its vicinity might represent a beginning point for further comparative cross-cultural ethnobotany that can contribute to enhancing the current knowledge of folk medicinal plants and lead to conservation plans for protecting rare plant species.

\section{Abbreviations}

UV: Use value

\section{Acknowledgments}

Special thanks to Ata Akgul, Velid Akgul, M. Halid Bilge and Cuneyt Akgul for help with fieldwork. We also thank Midyat Municipality government officials, local teachers, imams, priests, village headmen, and all participants in the survey. We thank Mr. Mehmet Tunc and Mr. Abdullah Uzuner for helping to obtain permission for Fig. 8. Additionally, we are indebted to Michelle Banes for manuscript editing.

\section{Funding}

Ege University provided financial support (\#2006 Fen 057) to Ali Akgul's Master research. There was no funding body in the writing of the manuscript or the decision to submit the manuscript for publication.

\section{Availability of data and materials}

Not applicable. We keep our surveys and some data secured because of the current regional security concerns.

\section{Authors' contributions}

AIA performed the fieldwork, collected and stored plants, AyA and AIA wrote and reviewed the manuscript, OS conceived the study and reviewed the manuscript, SgS and HY helped to identify plant taxa and prepared and stored herbarium samples. YD reviewed and edited the manuscript. All authors have read and agreed on the manuscript.

\section{Ethics approval and consent to participate}

The survey was conducted according to the guidelines of International Society of Ethnobiology Code of Ethics (http://ethnobiology.net/code-of-ethics/). Also, participation in the survey was voluntary and not obligatory, and participants were informed about the study objectives. There was no time limit to answer the survey questions. We obtained consent from the participants prior to this study being carried out.

\section{Consent for publication}

Permission to publish Fig. 8 was obtained; no permission is needed to publish other photos in figures.

\section{Competing interests}

The authors declare that they have no competing interests.

\section{Publisher's Note}

Springer Nature remains neutral with regard to jurisdictional claims in published maps and institutional affiliations.

\section{Author details}

'Department of Infectious Diseases \& Pathology, College of Veterinary Medicine, University of Florida, Gainesville, FL, USA. ${ }^{2}$ Department of Sustainable Bioproducts, College of Forest Resources, Mississippi State University, Starkville, MS, USA. ${ }^{3}$ Garden-Herbarium Research and Application Center, Ege University, Izmir, Turkey. ${ }^{4}$ Biology Department, Science Faculty, Ege University, Izmir, Turkey. ${ }^{5}$ Buca Faculty of Education, Dokuz Eylul University, Izmir, Turkey.
Received: 23 October 2017 Accepted: 11 December 2017

Published online: 07 February 2018

\section{References}

1. Kaval I, Behcet $L$, Cakilcioglu U. Ethnobotanical study on medicinal plants in Gecitli and its surrounding (Hakkari-Turkey). J Ethnopharmacol. 2014;155: 171-84

2. Muthu C, Ayyanar M, Raja N, Ignacimuthu S. Medicinal plants used by traditional healers in Kancheepuram District of Tamil Nadu, India. J Ethnobiol Ethnomed. 2006;2:43.

3. Dogan Y, Nedelcheva A, Luczaj L, Dragulescu C, Stefkov G, Maglajlic A, Maglajlic A, Ferrier J, Papp J, Hajdari A, Mustafa B, Dajić-Stevanović Z, Pieroni A. Of the importance of a leaf: the ethnobotany of sarma in Turkey and the Balkans. J Ethnobiol Ethnomed. 2015;11:26.

4. Yesilada E, Hondab G, Sezik E, Tabatab M, Fujitab T, Tanakac T, Takedad Y, Takaishi Y. Traditional medicine in Turkey. V. Folk medicine in the inner Taurus Mountains. J Ethnopharmacol. 1995;46(3):133-52.

5. Ertug F. Ethnobotany of Turkey. Resimli Turkiye Florasi. 2014;1:319-344.

6. Ertug F. Being a woman researcher in an Anatolian village. J Ethnobiol Ethnomed. 2013;9(1):45

7. Altundag E, Ozturk M. Ethnomedicinal studies on the plant resources of east Anatolia, Turkey. Procedia Soc Behav Sci. 2011;19:756-77.

8. Gurdal B, Kultur S. An ethnobotanical study of medicinal plants in Marmaris (Mugla, Turkey). J Ethnopharmacol. 2013;146(1):113-26.

9. Sargin SA, Akcicek E, Selvi S. An ethnobotanical study of medicinal plants used by the local people of Alasehir (Manisa) in Turkey. J Ethnopharmacol. 2013;150(3):860-74.

10. Hayta S, Polat R, Selvi S. Traditional uses of medicinal plants in Elazığ (Turkey). J Ethnopharmacol. 2014;154(3):613-23.

11. Mukemre $M$, Behcet $L$, Cakilcioglu U. Ethnobotanical study on medicinal plants in villages of Catak (Van-Turkey). J Ethnopharmacol. 2015;166:361-74.

12. Ozdemir E, Alpinar K. An ethnobotanical survey of medicinal plants in western part of central Taurus Mountains: Aladaglar (Nigde-Turkey). J Ethnopharmacol. 2015;166:53-65

13. Polat R, Cakilcioglu U, Kaltalioğlu K, Denizhan MD, Türkmen Z. An ethnobotanical study on medicinal plants in Espiye and its surrounding (Giresun-Turkey). J Ethnopharmacol. 2015;163:1-11.

14. Alzweiri M, Sarhan AA, Mansi K, Hudaib M, Aburjai T. Ethnopharmological survey of medicinal herbs in Jordan, the Nothern Badia region. J Ethnopharmacol. 2011:27-35.

15. Akan H, Korkut MM, Balos MM. An ethnobotanical study around Arat Mountain and its surroundings (Birecik Sanlıurfa). Sci Eng J Fırat Univ. 2008; 20:67-81.

16. Gencay F. Cizre (Şırnak)'nin etnobotanik özellikleri [Ethnobotanical aspects of Cizre (Şırnak)], MSc thesis. Van: Yüzüncü Yıl University; Department of Biology; 2007

17. Mardin Governor: http://www.mardin.gov.tr/ilcelerimiz/midyat. Accessed 12 April 2016.

18. Average of Incomes in cities of Turkey. Turkish Statistical Institute. http:// www.tuik.gov.tr/. Accessed 15 May 2015.

19. SilkRoad Dialogue, Diversity, and education. 2013. http://en.unesco.org/ silkroad/countries-alongside-silk-road-routes/turkey/. Accessed 26 May 2016.

20. Karluk SR, Karaman SC. Bridging civilizations from Asia to Europe: the silk road. Chinese. Bus Rev. 2014;13(2):730-9.

21. Elisseeff $V$. The Silk Roads: highways of culture and commerce. UNESCO Publishing/Berghahn Books; 2001.

22. Official statistics for climate-Mardin. Turkish State Meteorological Service. http://mgm.gov.tr.09/11/2015.archived. Accessed 2 June 2016.

23. Davis PH. Flora of Turkey and the East Aegean Islands, Vol. 1-9. Edinburgh University Press; 1988.

24. International Society of Ethnobiology 2006. International Society of Ethnobiology Code of ethics (with 2008 additions). http://ethnobiology.net/ code-of-ethics/. Accessed 16 May 2017

25. Trotter RT, Logan MH. Informant consensus: a new approach for identifying potentially effective medicinal plants. In: Etkin NL, editor. Plants in indigenous medicine and diet: biobehavioral approaches. New York: Redgrave Publishing Company; 1986. p. 91-112.

26. Çakılcıoğlu U, Turkoglu I. Plants used for hemorrhoid treatment in Elazig central district. International Medicinal and Aromatic Plants Conference Proceedings on Culinary Herbs. 2007; p. 826. 
27. Bahramikia S, Yazdanparast R. Phytochemistry and medicinal properties of Teucrium polium L. (Lamiaceae). Phytother Res. 2012;26(11):1581-93.

28. Sigva HO, Secmen O. Ethnobotanic survey of Işklı (Çarpın), Dağdancık and Tokdemir in Gaziantep, Turkey. IUFS J Biology. 2009;68:19-26.

29. Gonzalez-Tejero MR, Casares-Porcela M, Sánchez-Rojasa CP, RamiroGutiérreza JM, Molero-Mesa J, Pieroni A, Giustic ME, Censorii E, Pasquale C, Dellad A, Paraskeva-Hadijchambi D, Hadjichambis A, Houmani Z, ElDemerdash Z, El-Zayat M, Hmamouchi M, ElJohrig S. Medicinal plants in the Mediterranean area: synthesis of the results of the project Rubia. J Ethnopharmacol. 2008;116(2):341-57.

30. Ghorbani A. Studies on pharmaceutical ethnobotany in the region of Turkmen Sahra, north of Iran (part 1): general results. J Ethnopharmacol. 2005;102(1):58-68.

31. Aburjai T, Hudai M, Tayyem R, Yousef M, Qishawi M. Ethnopharmacological survey of medicinal herbs in Jordan, the Ajloun Heights region. J Ethnopharmacol. 2007;110(2):294-304.

32. Sezik E, Yeşilda E, Tabata M, Honda G, Takaishi Y, Fujita T, Tanaka T, Takeda Y. Traditional medicine in Turkey VIII. Folk medicine in East Anatolia; Erzurum, Erzincan, Ağri, Kars, lğdir Provinces. Econ Bot. 1997:51(3):195-211.

33. Kheder FHB, Mahjoub MA, Zaghrouni F, Kwaja S, Helal AN, Mighri Z. Chemical composition antioxidant and antimicrobial activities of the essential oils of Matricaria aurea Loefl. growing in Tunisia. J Essent Oil Bear PI. 2014;17(3):493-505.

34. Ozgen U, Kaya Y, Coşkun M. Ethnobotancal studies in the villages of the district of Ilica (province Erzurum), Turkey. Econ Bot. 2004;58(4):691-6.

35. Ozgokçe F, Ozcelik H. Ethnobotanical aspects of some Taxa in east Anatolia, Turkey. Econ Bot. 2004;58(4):697-704.

36. Tuzlacı E, Aymaz PE. Turkish folk medicinal plants, part IV: Gönen (Balıkesir) Fitoterapia. 2001;72(4):323-43.

37. Ozturk M, Ozcelik H. Dogu Anadolu'nun faydalı bitkileri (Useful plants of East Anatolia). Siirt: Siirt Ilim, Spor, Kültür ve Araştırma Vakfı; 1991.

38. Turkoğlu I. Investigation of ethnobotanical taxons in Elazığ, MSc thesis. Elazığ: Fırat University, Department of Biology; 2000.

39. Akan H, Sade YB. An ethnobotanical study in Adiyaman Kahta and Narenciye village, MSc thesis. Sanliurfa: Harran University, Department of Biology; 2013.

40. Lev E, Amar Z. Ethnopharmacological survey of traditional drugs sold in the kingdom of Jordan. J Ethnopharmacol. 2002;82(2-3):131-45.

41. Gumus I. Ağrı yöresinde yetişen bazı faydalı bitkilerin yerel adları ve kullanıışları. Turk J Bot. 1994;18:107-12.

42. Miraldi E, Ferri S, Mostaghimi V. Botanical drugs and preparations in the traditional medicine of West Azerbaijan (Iran). J Ethnopharmacol. 2001;75(23):77-87.

43. Asgarpanah J, Ramezanloo F. Chemistry, pharmacology and medicinal properties of Peganum harmala L. Afr J Pharm. 2012;6(22):1573-80.

44. Ozgokce F, Yilmaz I. Dye plants of east Anatolia region (Turkey). Econ Bot. 2003:57(4):454-60

45. Tetik F, Civelek S, Cakilcioglu U. Traditional uses of some medicinal plants in Malatya (Turkey). J Ethnopharmacol. 2013;146(1):331-46.

46. Polat R, Cakilcioglu U, Satıl F. Traditional uses of medicinal plants in Solhan (Bingöl_-Turkey). J Ethnopharmacol. 2013;148(3):951-63.

47. Ozturk F, Olcucu C. Ethnobotanical features of some plants in the district of Semdinli (Hakkari-Turkey). Int J Ac Res. 2011;3(1):117-21.

48. Dogan Y, Nedelcheva A. Wild plants from open markets on both sides of the Bulgarian-Turkish border. Indian J Tradit Know. 2015;14(3):351-8.

49. Sõukand R, Pieroni A. The importance of a border: medical, veterinary, and wild food ethnobotany of the Hutsuls living on the Romanian and Ukrainian sides of Bukovina. J Ethnopharmacol. 2016;185:17-40.

50. Ahmad AS, Askari AA. Ethnobotany of the Hawraman region of Kurdistan Iraq. Harv Pap Bot. 2015;20:85-9.

51. Polat R, Cakilcioglu U, Ertug F, Satil F. An evaluation of ethnobotanical studies in eastern Anatolia. Biol Diversity Conserv. 2012:5(2):23-40.

52. Akgul A, An Ethnobotanical study in Midyat (Mardin) and its vicinity, MSC thesis. Izmir: Ege University, Department of Biology. 2008.

53. Midyat newspaper MIDYATWEB. 2016. http://www.midyatweb.com/midyat ta-suryaniler-paskalya-bayramini-kutladi/2790/. Accessed 12 Mar 2017.

54. Yapıcı UI, Hosgoren H, Saya O. Ethnobotanical features of Kurtalan (Siirt) district. Dicle University. J Ziya Gokalp Edu Fac. 2009;12:191-6.

55. Balos MM, Akan H. Zeytinbahge-Akargay (Birecik, Sanliurfa) arasında kalan bolgenin etnobotanik ozellikleri. Suleyman Demirel University J Sci and Lit Fac. 2007;29:155-71.
56. Güner A, Aslan S, Ekim T, Vural M, Babaç MT. The list of Plants in Turkey. Istanbul: Flora Araştırmaları Derneği ve Nezahat Gökyiğit Botanik Bahçesi Yayını (in Turkish); 2012. p. 14.

57. Dogan Y, Baslar S, Mert HH, Ay G. Plants used as natural dye sources in Turkey. Econ Bot. 2003;57(4):442-53.

58. Boudjelal A, Henchiri C, Sari M, Sarri D, Hendel N, Benkhaled A, Ruberto G. Herbalists and wild medicinal plants in M'Sila (North Algeria): an ethnopharmacology survey. J Ethnopharmacol. 2013;148(2):395-402.

59. Aysu T, Durak H, Güner S, Bengü AŞ, Esim N. Bio-oil production via catalytic pyrolysis of Anchusa azurea: Effects of operating conditions on product yields and chromatographic characterization. Bioresour Technol. 2016;205:714. https://doi.org/10.1016/j.biortech.2016.01.015.

60. Çakilcioǧlu U, Sengun MT, Turkoglu I. An ethnobotanical survey of medicinal plants of Yazikonak and Yurtbaşi districts of Elazığ province, Turkey. J Med Plants Res. 2010;4(7):567-72.

61. Ahmed S, Hasan MM, Mahmood ZA. Antiurolithiatic plants in different countries and cultures. J Pharmacogn Phytochem. 2016;5(1):102-15.

62. Khan RU, Mehmood S, Khan SU, Subhan M. Ethnobotanical study of common weed flora of sugarcane in district Bannu, Khyber Pakhtunkhawa, Pakistan. J Med Plants Res. 2013;1:49-78.

63. Citoglu GS, Tanker M, Sever B, Englert J, Anton R, Altanlar N. Antibacterial activities of diterpenoids isolated from Ballota saxatilis subsp. saxatilis. Planta Med. 1998;64:484-5.

64. Arnold N, Baydoun L, Raus CT. A contribution to the flora and ethnobotanical knowledge of mount Hermon. Lebanon FI Medit. 2015;25:13-55.

65. Al-Qura'n S. Ethnopharmacological survey of wild medicinal plants in Showbak. Jordan J Ethnopharmacol. 2009;123(1):45-50.

66. Ugulu I. Traditional ethnobotanical knowledge about medicinal plants used for external therapies in Alasehir, Turkey. Int J med Arom. Plants. 2011;1(2): 101-6.

67. Sagıroğlu M, Topuz T, Ceylan K, Turna M. An ethnobotanical survey from Yahyalı (Kayseri) and tarsus (Mersin). Sakarya University J Sci and Lit. 2013;2: 13-37.

68. Koyuncu O, Yaylacı O, Tokur S. A study on Geyve (Sakarya) and its environs in terms of ethnobotanical aspects. The Herb J Sys Bot. 2009;16:123-42.

69. Polat R, Satı F. An ethnobotanical survey of medicinal plants in Edremit gulf (Balıkesir - Turkey). J Ethnopharmacol. 2012;139(2):626-41.

70. Cakilcioglu U, Turkoglu I. An ethnobotanical survey of medicinal plants in Sivrice (Elazı̆̆-Turkey). J Ethnopharmacol. 2010;132(1):165-75.

71. Ezer N, Mumcu Arisan O. Folk medicines in Merzifon (Amasya, Turkey). Turk J Bot. 2006:30(3):223-30

72. Leto C, Tuttolomondo T, La Bella S, Licata M. Ethnobotanical study in the Madonie Regional Park (central Sicily, Italy)-medicinal use of wild shrub and herbaceous plant species. J Ethnopharmacol. 2013;146(1):90-112.

73. Tita I, Mogosanu GD, Tita MG. Ethnobotanical inventory of medicinal plants from the south-west of Romania. Farmacia. 2009;57(2):141-56.

74. Sher Z, Khan ZUD, Hussain F. Ethnobotanical studies of some plants of Chagharzai Valley, district Buner, Pakistan. Pak J Bot. 2011;43(3):1445-52.

75. Kaval I, Behcet L, Cakilcioglu U. Survey of wild food plants for human consumption in Gecitli (Hakkari, Turkey). Indian J Tradit Know. 2014; 14(2):183-90.

76. Kizilarslan C, Ozhatay N. An ethnobotanical study of the useful and edible plants of Izmit. Marmara Pharm J. 2012;16:134-40.

77. Kilic O, Bagci E. An ethnobotanical survey of some medicinal plants in Keban (Elazı̆̆ Turkey). J Med Plants Res. 2013:7(23):1675-84.

78. Kargioglu M, Cenkci S, Serteser A, Evliyaoğlu N, Konuk M, Şamil Kök M, Bagci Y. An Ethnobotanical survey of inner-west Anatolia, Turkey. Hum Ecol. 2008;36(5): 763-77.

79. Baydoun S, Lamis C, Helenaa D, Nelly A. Ethnopharmacological survey of medicinal plants used in traditional medicine by the communities of mount Hermon. Lebanon J Ethnopharmacol. 2015;173:139-56.

80. Eruygur N, Yılmaz G, Kutsal O, Yücel G, Üstün O. Bioassay-guided isolation of wound healing active compounds from Echium species growing in Turkey. J Ethnopharmacol. 2016;5(185):370-6. https://doi.org/10.1016/j.jep.2016.02.045.

81. Çakıloğlu U. Harput (Elazığ) ve çevresinin etnobotanik özellikleri. East Anatolia Res. 2007:22-8.

82. Tabata M, Sezik E, Honda G, Yeşilada E, Fukui H, Goto K, Ikeshiro Y. Traditional medicine in Turkey III. Folk medicine in east Anatolia, van and Bitlis provinces. Pharm Biol. 1995;32(1):3-12.

83. Ozgen U, Kaya Y, Houghton P. Folk medicines in the villages of Ilıca District (Erzurum, Turkey). Turk J Biol. 2012;36:93-146. 
84. Ozudoğru B, Akaydın G, Erik S, Yesilada E. Inferences from an ethnobotanical field expedition in the selected locations of Sivas and Yozgat provinces (Turkey). J Ethnopharmacol. 2011;137(1):85-98.

85. Kocak S, Ozhatay N. Wild edible plants in Karaman (southern Turkey). J Fac Pharm Istanbul. 2013;43(1):21-32.

86. Korkmaz M, Alparslan Z, Turgut N, Ilhan V. Ethnobotanical aspects of some geophytes from Ergan Mountain, Turkey. Bangladesh J Bot. 2014;43(3):315-21.

87. Cakilcioglu U, Khatun S, Turkoglu I, Hayta S. Ethnopharmacological survey of medicinal plants in Maden (Elazığ -Turkey). J Ethnopharmacol. 2011;137:469-86.

88. Arasan S, Kaya I. Some important plant belonging to Asteraceae Family used in folkloric medicine in Savur, Turkey area and their application areas. J Food Nutr Res. 2015;3:337-40.

89. Sagiroglu M, Dalgic S, Toksoy S. Medicinal plants used in Dalaman (Muğla), Turkey. J Med Plants Res. 2013;7(28):2053-66.

90. Ahmet Sargin S. Ethnobotanical survey of medicinal plants in Bozyazı district of Mersin, Turkey. J Ethnopharmacol. 2015;15(173):105-26. https:// doi.org/10.1016/j.jep.2015.07.009.

91. Arı S, Temel M, Kargığlu M, Konuk M. Ethnobotanical survey of plants used in Afyonkarahisar-Turkey. J Ethnobiol Ethnomed. 2015;11:84.

92. Eren SB, Ozturk B, Sahin B, Senol S. The medical plants used around the world heritage site Mount Nemrut, Adiyaman (Turkey). XI International Ethnobotany Symposium Conference Proceedings. 2013; p.79.

93. Ali-Shtayeh MS, Yaniv Z, Mahajna J. Ethnobotanical survey in the Palestinian area: a classification of the healing potential of medicinal plants. Ethnopharmacol. 2000;73(1-2):221-32.

94. Akan $\mathrm{H}$, Ayaz H. Gölpınar (Şanlıurfa-Türkiye) mesire yeri florası ve etrafındaki köylerin etnobotanik özellikleri. J Bağbahçe Bilim. 2015;2(3):19-56.

95. Ozturk M, Uysal I, Gucel S, Altundag E, Dogan Y, Baslar S. Medicinal uses of natural dye-yielding plants in Turkey. Res J Text Appar. 2013;17(2):69-80.

96. Ugurlu I. Traditional ethnobotanical knowledge about medicinal plants used for external therapies in Alasehir, Turkey. Int J med Arom. Plants. 2011;2:101-6.

97. Ad T, Luczaj LJ, Quave CL, Redzic S, Pieroni A. Traditional food and herbal uses of wild plants in the ancient South-Slavic diaspora of Mundimitar/ Montemitro (Southern Italy). J Ethnobiol Ethnomed. 2012;8:21.

98. Apaydin AM, Aydin M, Ciftci O, Timurkaan N, Yildiz H, Tonbak S. Effects of Paronychia kurdica on teat and udder papillomatosis in cows. Rev Med Vet. 2010;161(6):267-71.

99. Gonzalez JA, Garcia-Barriuso M, Amich F. Ethnobotanical study of medicinal plants traditionally used in the Arribes del Duero, western Spain. J Ethnopharmacol. 2010;131(2):343-55.

100. Korkmaz M, Karakus S. Traditional uses of medicinal plants of Uzumlu district, Erzincan, Turkey. Pak J Bot. 2015;47(1):125-34.

101. Sarper F, Akaydin G, Simsek I, Yesilada E. An ethnobotanical field survey in the Haymana District of Ankara Province in Turkey. Turk J Biol. 2009;33:79-88.

102. Polat R, Cakilcioglu U, Ulusan MD, Paksoy MY. Survey of wild food plants for human consumption in Elazığ (Turkey). Indian J Tradit Know. 2015;1(1):69-75.

103. Ertug F. An ethnobotanical study in central Anatolia (Turkey). Econ Bot. 2000;54:155-82.

104. Dolatkahahi M, Dolatkahahi A, Nejad JB. Ethnobotanical study of medicinal plants used in Arjan-Parishan protected area in Fars Province of Iran. Avicenna J Phytomed. 2014;4(6):402-12.

105. Akgul G, Yilmaz N, Celep A, Celep F, Cakilcioglu U. Ethnobotanical purposes of plants sold by herbalists and folk bazaars in the center of Cappadocica (Nevsehir, Turkey). Indian J Tradit Know. 2016:103-8.

106. Demirci S, Ozhatay N. An ethnobotanical study in Kahramanmaraş (Turkey); wild plants used for medicinal purpose in Andirin, Kahramanmaraş. Turk J Pharm Sci. 2012;9(1):75-92.

107. Akaydin G, Simsek I, Arituluk ZC, Yesilada E. An ethnobotanical survey in selected towns of the Mediterranean subregion (Turkey). Turk J Biol. 2013;37:230-47.

108. Bulut G, Tuzlaci E. An ethnobotanical study of medicinal plants in Bayramiç (Çanakkale Turkey). Marmara Pharm J. 2015;19:268-82.

109. Bulut G. Medicinal and wild food plants of Marmara Island (Balikesir-Turkey). Acta Soc Bot Pol. 2016;85(2):3501

110. Senol SG, Secmen O, Eroglu V, Sahin B. Brooms of Turkey. XI International Ethnobotany Symposium Conference Proceedings. 2013; p.76.

111. Akan H. An ethnobotanical investigation on the basket of Mardin. South East Anatolia Adyutayam. 2013;1:21-30.

112. Kalankan G, Ozkan ZC, Bulut S. Medicinal and aromatic wild plants and traditional usage of them in Mount Ida (Balıkesir/Turkey). J Appl Biol Sci. 2015;9(3):25-33.

\section{Submit your next manuscript to BioMed Central and we will help you at every step:}

- We accept pre-submission inquiries

- Our selector tool helps you to find the most relevant journal

- We provide round the clock customer support

- Convenient online submission

- Thorough peer review

- Inclusion in PubMed and all major indexing services

- Maximum visibility for your research

Submit your manuscript at www.biomedcentral.com/submit
Biomed Central 